\title{
A toxikológia rövid története - a tapasztalattól a tudományig
}

\author{
Tompa Anna dr. - Balázs Péter dr.
}

Semmelweis Egyetem, Általános Orvostudományi Kar, Népegészségtani Intézet, Budapest

\begin{abstract}
A toxikológia a xenobiotikumok és az endogén fiziológiai folyamatok okozta mérgező hatások tudománya. Empirikus előzményei visszavezetnek az emberré válás folyamatáig, hiszen eleink életben maradásának egyik fontos záloga volt az ehetô és a mérgező növények, illetve állatok elkülönítése. Az emberiség fejlődésének kiteljesedő folyamatában a mérgek használata három fó területen jelent meg: 1) a vadászatban, majd a hadviselésben, 2) békeidóben az ellenfelek megmérgezésében, miután a rejtőzködő stratégia jellemzően előnyösebbnek bizonyult a nyíltan alkalmazott durva fizikai eszközöknél, és 3 ) a gyógyászatban az ellenmérgek, majd a betegségeket legyőző erős anyagok révén, de paradox módon az orvoslási segédlettel végrehajtott emberölést, vagyis az aktív eutanáziát is idesorolhatjuk. A XIX. század ipari forradalma az addig marginális foglalkozási ártalmakat népbetegséggé tette, majd a vegyipar forradalma és a mű́anyagok tömegtermelése a XXI. században globális környezeti katasztrófával fenyegeti az emberiséget. Ez a változás a humántoxikológia után az ökológiai toxikológia színrelépését eredményezte, ami már nem történelme, hanem jövője ennek a tudománynak.
\end{abstract}

Orv Hetil. 2018; 159(3): 83-90.

Kulcsszavak: toxikológia, történelem, mérgek, orvoslás, mérgezések

\section{Concise history of toxicology - from empiric knowledge to science}

Toxicology is a science of poisonings by xenobiotics and endogenous physiological changes. Its empiric roots may be traced back to the emerging of the human race because the most important pledge of our predecessors' survival was the differentiation between eatable and poisonous plants and animals. In the course of social evolution, there were three main fields of using poisons: 1) hunting and warfare, 2) to settle social tensions by avoiding military conflicts through hiding strategy of eliminating enemies by toxic substances, 3) medicines applied first as anti-poisons and later by introducing strong substances to defeat diseases, but paradoxically active euthanasia is also a part of the whole story. The industrial revolution of the 19th century changed the sporadic occupational diseases to mass conditions. Later the chemical industry and subsequently the mass production of synthetic materials turned out as a global environmental catastrophe. This latest change initiated the emerging of ecological toxicology which is a future history of the concerning ancient science.

Keywords: toxicology, history, toxic substances, medicine, poisonings

Tompa A, Balázs P. [Concise history of toxicology - from empiric knowledge to science]. Orv Hetil. 2018; 159(3): 83-90.

(Beérkezett: 2017. október 5.; elfogadva: 2017. október 30.)

Semmelweis Ignácz születése 200. évfordulójának évében a Szerkesztőség felkérésére készített tanulmány.

A toxikológia a xenobiotikumok és az endogén fiziológiai folyamatok okozta mérgező hatások tudománya. Empirikus előzményei visszavezetnek az emberré válás kezdetéig, hiszen eleink életben maradásának egyik fontos záloga volt az ehető és a mérgező növények, illetve álla- tok elkülönítése. Az evolúció során jelentős fordulatot hozott a vadon élő állatok tömeges háziasítása és a rideg módszerek mellett az istállózó állattartás megjelenése, amelynek során az emberek gondoskodtak az állatok (például lovak, tevék, szarvasmarhák, juhok, kecskék, 
sertések) etetéséről és itatásáról. A takarmányba keveredő gyakori mérgező növénynek számított például a beléndek (Hyoscyamus niger), a csattanó maszlag (Datura stramonium), a nadragulya (Atropa belladonna), a foltos bürök (Conium maculatum) vagy az őszi kikerics (Colchicum autumnale).

A toxikológia klasszikus időszakában a mérgek használata három fó területen jelent meg: 1) a vadászatban és a hadviselésben, 2) háborúkon kívül az ellenfelek megmérgezésében, és 3) a gyógyászatban ellenméregként, majd „erős” anyagként a betegségek ellen, de paradox módon az orvoslási segédlettel végrehajtott emberölés, vagyis az aktív eutanázia is része a mérgek és mérgezések történetének.

Történelmileg az a tudomány, amelyet ma toxikológiának nevezünk, a legtágabban értelmezett európai típusú kultúrából alakult ki, amelynek eredete a Nílus, az Eufrátesz és a Tigris, illetve az Indus mentén keletkezett civilizációkra, majd a hellén, a római és az arab birodalomra vezethető vissza. A távol-keleti holisztikus gondolkodással szemben a mindent apró részeire bontó észjárás igyekezett az anyag titkainak mélyére hatolni, hogy azután a legkisebb részecskékből összerakva a világot újra teljességében láthassa. Ez a gondolkodásmód vezetett az alkímián át az analitikus kémiáig, amely egész mai modern világunkat meghatározza.

\section{Hadászati alkalmazások}

Mai terminológiával a fegyveres konfliktusokban használt mérgeket a kémiai hadviselés eszköztárába soroljuk. Ezek a hadi anyagok a tömegpusztító ABC- (atomic-biological-chemical; atom-, biológiai, vegyi) fegyverek közé tartoznak, a folyamat azonban a prehisztorikus korban a mérgezett nyílvesszőkkel és a hajító kézifegyverekkel kezdődött. Pedaniosz Dioszkoridész (Kr. u. 40-90), az ókor legnagyobb botanikusa és farmakológusa szerint maga a toxin kifejezés is a görög „toxon” (nyílvessző) szóra vezethető vissza. Harctéri küzdelmek kapcsán számos legenda született Nagy Sándor (Kr. e. 356-323) hellén hadvezér mérgezett nyilak és dárdák által okozott sérüléseiről. Leginkább hitelesnek tekinthető ókori történetírójának, Plutarkhosznak (Kr. u. 46-120) azonban ilyen mérgezett sebekről nem volt tudomása [1]. Sérüléseinek irodalomkritikai kutatása alapján erre a legújabb katonai szakirodalomban sem találtak adatokat [2]. A legutóbbi feltételezések szerint Nagy Sándor halálát a fehér zászpa (Veratrum album) nevü növényből készített és borba kevert méreg okozta [3].

Hadviselő felek között gyakori technika volt a víztározók megmérgezése, mivel más anyagokkal ellentétben a vizet nem lehetett felégetni. Mérgező harci eszközök első tömegméretű bevetésére az I. világháborúban került sor, jóllehet az 1899. évi hágai egyezmény, majd az 1907-es nemzetközi hadi eljárási szabályzat is megtiltotta a fulladást vagy mérgezést okozó harci gázok alkalmazását. Ennek ellenére a hadviselő felek mindkét oldalon végeztek kisebb sikertelen kísérleteket, azonban az első sikeres támadást a német hadsereg hajtotta végre klórgázzal a belgiumi Ypres melletti harctéren, 1915. április 22-én. Hatására 5000 katona halt meg, és 15000 vált harcképtelenné [4]. A vegyipar XX. századi fejlődése nyomán ezeknek az eszközöknek a fejlesztése minden tiltás ellenére tovább folytatódott. Legújabb csoportjukba az idegmérgek, illetve a különböző, főként gáznemú tudatmódosító szerek tartoznak. Rejtett raktárakban ma is tárolnak ilyen szereket, de helyileg korlátozott és kisebb méretû felhasználásukat minden esetben óriási nemzetközi felháborodás kíséri.

\section{Mérgek a társadalmi konfliktusok kezelésében}

A prehisztorikus korból átörökített történeteket a legteljesebb módon az ógörög mitológia őrizte meg számunkra. Mérgek az istenek és félistenek vitáiban vagy versengésében is szerephez jutottak. A szóbeli hagyományt a klasszikus görög irodalom is feldolgozta. Euripidész (Kr. e. 480-406) tragédiája nyomán így vált Médeia az antikvitás legjellegzetesebb méregkeverő nőalakjává [5], de történetének számos újkori értelmezése és feldolgozása alapján az általa megszemélyesített női sorsból sokféle más értelmezés is levezethető. Aigeosz athéni király egy házasságon kívüli kapcsolatából született Thészeusz, a király azonban Médeiát vette feleségül, akitől törvényes fia született. Thészeusz jeles harcossá érett, és számos hőstettet vitt véghez, majd egyik vándorútja során apját, Aigeoszt is meglátogatta, aki egyébként nem tudott a létezéséről. Médeia viszont mindent tudott, és a hőssel mérget akart itatni. Apja azonban felismerte a fiát, és kiütötte a poharat a kezéből, Médeiát pedig a tőle született fiával együtt elűzte az országból.

Mérgezések a germán mitológiából és mesevilágból is fennmaradtak, amelynek legkiválóbb kutatói a Grimm testvérek, Jacob (1785-1863) és Wilhelm (1786-1859) voltak. Gyüjtésükből maradt fenn a mérgezett alma története a Hófehérke és a hét törpe klasszikus meséjében. A gonosz mostoha harmadik gyilkossági kísérlete során mérgezett almát kínált Hófehérkének, aki csak azért menekült meg a haláltól, mert az almából harapott darab a torkán akadt, amitől elájult, és így módjában volt a királyfinak megmentenie.

A mérgek használata a politikában sem volt ismeretlen. Az egyik legrégibb történet Szókratészről (Kr. e. 469399) szól, a klasszikus görög filozófia alapítójától, akit Athénben istentelenség vádjával halálra ítéltek. Bár lehetősége lett volna elmenekülni valamelyik távoli szigetre, ő a foltos bürök kivonatával öngyilkosságot követett el. Pontosz királya az ókori Anatóliában, VI. Mithridatész Eupatór (Kr. e. 132-63) annyira rettegett a mérgezéstől, hogy halálos dózis alatti mérgek szedésével akart védettséget szerezni. Ezen túl kifejlesztett egy legalább ötvenféle anyagból összeállított általános ellenmérget, amelyet először De Medicina című múvében Aulus Cornelius 
Celsus (Kr. e. 25-Kr. u. 50) nevezett Antidotum Mithridaticumnak. Később számos orvos, így Pergamoni Galénosz (129-199) is azt állította magáról, hogy ismeri az antidotum pontos receptjét. Ezzel az állítással a középkori orvosok is sikereket értek el, ugyanis az antidotumok kérdése mindig is érdekelte az uralkodókat, hiszen állandó félelemben éltek, hogy a személyzet vagy az ellenség beépített emberei meggyilkolják őket. Ezért előkóstoltatták vagy a kutyáknak adták a felszolgált ételeket és italokat. Ha ártalmatlannak bizonyultak, hozzákezdhettek a fogyasztásukhoz. Minden eshetőséget számításba véve azonban orvosaiktól elvárták, hogy szükség esetén az ellenméreg adására is felkészülttek legyenek.

Kleopátra (Kr. e. 69-30), az egyiptomi Ptolemaioszdinasztia utolsó uralkodója igen tájékozott volt a mérgek területén. Óriási alexandriai könyvtárában fellelhetők voltak az akkor ismert világ összes tudósának múvei. Testvérházasságban élt öccsével, majd amikor az hatalmi pozícióját fenyegette, egyszerúen megmérgezte. Végül az ő halálát is saját fegyvere okozta, miután hatalmi pozíciója meggyengült a rómaiak ellen folytatott sikertelen küzdelemben. A Kr. e. 30-ban elszenvedett döntő vereség után áspiskígyóval maratta meg magát, hogy elkerülje a meghurcoltatást és a megalázást.

A lex Cornelia de sicariis et veneficis (az orgyilkosokról és mérgezőkről) Lucius Cornelius Sulla (Kr. e. 13878 ) diktátorságának idejétől büntette azokat, akik méreggel gyilkosságokat követtek el [6]. Ez volt az első törvény a római jogban, amely a mérgezést büntetendőnek nyilvánította, de ettől nem csökkent az ilyen cselekmények száma. Sőt a császárkori Róma első évszázadában Néró (ur. Kr. u. 54-68) édesanyja, Agrippina volt a város egyik legveszedelmesebb méregkeveróje. Fiának útját egyengetve a hatalom felé, gombával mérgezte meg második férjét, Claudius császárt (ur. Kr. u. 41-54). Agrippina császárrá lett fiával is ellentétbe került, és megfenyegette, hogy ellenében Claudius fiát, Britannicust fogja támogatni. Erre Néró Britannicust Kr. u. 55-ben arzénnel meggyilkoltatta. A birodalom hanyatlása során olyan gyakorivá váltak a politikai okokból elkövetett mérgezések, hogy a császárok közül ilyen találgatások Domitianus (ur. Kr. u. 81-96), Hadrianus (ur. 117-138) és Commodus (ur. 177-192) halála kapcsán is felmerültek. Kétségtelen, hogy Commodus halálát egy sikertelen mérgezési kísérlet után erôszakos gyilkosság okozta.

A Római Birodalom nyugati részének bukása (476) után a kora középkor (476-1000) végén arab hatásra kibontakozó alkímia „tudományos” vegytani hátteret adott az empirikus méregkeverésnek. Első törekvései arra irányultak, hogy értéktelen ásványokból, fémekből aranyat állítsanak elő. Miután ez nem sikerült, az alkimisták kiterjesztették tevékenységüket az életelixírek felkutatására, fóleg az örök ifjúság és a férfierő, végül az élet titkát keresték. Kémiai módszerekkel manipulálták a természetes anyagokat, így például az arzénvegyületeket színtelen, szagtalan porrá alakították, így a halálos veszélyt ízről vagy szagról sem lehetett észlelni. Rájöttek, hogy a folyamatosan kis adagokban beadott arzén csak hónapok múlva okoz halált, így a tettes kiléte is rejtve maradhatott. Ilyen alkalmazással az arzén krónikus betegséghez hasonló tüneteket okoz, enyhe hasmenés, majd székrekedés, fogyás, időszakos láz, hányás, köhögés, gyomorbajra utaló fájdalmak stb. kíséretében. Így vált az arzén a méregkeverő gyilkosok ideális anyagává. Másfelől az akut arzénmérgezés tünetei (magas láz, hányinger, hányás, hasmenés) kifejezetten hasonlítottak a középkor higiénés viszonyai mellett igen gyakori heveny gyomor-bél rendszeri fertőző betegségekhez, ami az arzént a gyors elkövetésekben is alkalmazhatóvá tette. A késő középkorban és az újkor kezdetén (1400-1500as évek) arzénnel elkövetett gyilkosságok kapcsán az itáliai Borgia család vált a leginkább hírhedtté. Tagjai nemcsak hatalmas testi erővel és kiváló szellemi képességekkel rendelkeztek, de korlátlan hatalomvágyukban mérhetetlenül erkölcstelenek is voltak. Főként az utókor tette félelmetessé Lucrezia Borgiát (1480-1519) mint a méregkeverők leggyúlöltebb női képviselőjét.

Leonardo da Vinci (1452-1519) is kapott olyan feladatot, hogy mérgezett gyümölcsöket állítson elő arzénes locsolással. Ez a módszer azért nem vált be, mert a növény életfolyamatai és vízháztartása jelentősen felhígította és eliminálta a mérget. Leonardo viszont részletes feljegyzéseket készített a „mérgezett” almafákról, és megállapította, hogy a kártevők nem támadják meg, és a fák igen szép egészséges termést hoznak. Valójában első növényvédő szerként így fedezte föl az arzént.

A társadalmi konfliktusok, a járványok és az éhezés még az újkor (1492-1789) végéig fenntartotta a mérgek archaikus alkalmazásának gyakorlatát. Tanulatlan javasasszonyok, füvesemberek és boszorkányok gyógyfüveket, főzeteket, varázsigéket és más különböző praktikákat alkalmaztak arra, ha valakinek hútlen volt a házastársa, vagy nem fejlődött kellőképpen a gyermeke, vagy akart, illetve nem akart gyermeket szülni. Átkokat és rontást vettek le, vagy éppen fordítva, a szemmel verést gyakorolták, ha valakire megharagudtak. Ismerték a fájdalomcsillapítás fortélyait, ugyanis ügyesen alkalmazták a kábítószereket, továbbá hallucinációkat, illetve memóriazavarokat okozó mágikus gombákkal mesterkedtek. A kereszténység egyházi szervezete üldözte ezeket az embereket, mert eretneknek tartották őket. Magyarországon a kereszténység előtti ôsi démonológia és az új hit közötti összeütközésnek a legismertebb példája Könyves Kálmán (ur. 1095-1114) I. törvénykönyve, amelynek 57. szakasza rendelkezett a pogány boszorkányokról: „de strigis vero quae non sunt, nulla questio fiat”, vagyis azokról a boszorkányokról, akik valójában nem léteznek, semmilyen vizsgálat ne kezdődjék [7]. Könyves Kálmán tehát nem az 1300-as években kibontakozó keresztény inkvizíció maleficának nevezett boszorkányairól rendelkezett, hanem strix néven a pogány rossz szellemekről. A Szentszék által 1484-től hivatalossá tett üldözések következtében mintegy 6 millió boszorkányt égettek el, többnyire koholt vádak alapján. Magyarorszá- 
gon a perek egészen a XVIII. század közepéig folytatódtak. Végül Mária Terézia 1768. május 26-án hatályba lépett rendeletével (Processus iudiciari de magia abrogantur) betiltotta a boszorkányok üldözését [8].

Sajnos a mérgezések gyakorlata ma sem csillapodik, a kriminológia gyakran találkozik elvetemült méregkeverőkkel, de a politikusok megmérgezése sem ritkaság, gondoljunk csak a 2004-ben ukrán elnökjelölt Viktor Juscsenko dioxinmérgezésére, vagy 2017-ben az északkoreai elnök féltestvérének, Kim Dzsong Namnak harci gázzal történt meggyilkolására.

\section{Gyógyászati alkalmazások}

A törzsi varázslók és sámánok kora után az első jelentős fordulat akkor következett be, amikor megkezdődött az empirikus tudásanyag rendszeres összegzése és elméleti keretbe foglalása, vagyis a tudományos gondolkodás, és megjelentek a tudományok. Az írásbeliség mintegy ötezer éves fejlemény az emberiség történetében. Sumer és óegyiptomi feljegyzésekben ennek köszönhetjük az első adatokat, amelyek az emberi vagy állati szervezetre gyakorolt toxikus hatásokról szólnak. A babiloni és asszír terápiás szövegek is számos növényi és állati eredetü anyagról számolnak be, azonosításuk azonban lényegesen nehezebb, mint az óegyiptomi papiruszok esetében. Az Ebers-papirusz korábbi feljegyzések másolatait tartalmazza. Legrégibb részei 3500 évvel ezelőtt keletkezhettek. Leírásaiban számos, ma is használatos gyógyszer alapanyaga szerepel, mint például az ópium, de a kaktuszok kivonatai, az aloék, a bürök vagy a digitálisz alapanyagának forrása, a gyưszúvirág is megjelenik a leírásokban [9]. Számos füszerről (például kömény vagy sáfrány), illetve jó néhány ásványról, fémról is említést tesznek a papiruszok az ólom mérgező hatása mellett.

Mai értelmezésünk szerint a természettudományos orvoslás megalapítója Hippokratész (Kr. e. 460-375), akit az „orvostudományok atyjának” is neveznek, szintén foglalkozott a mérgezésekkel, azok tüneteivel és gyógyításával. A Hippokratészi Gyújteményben foglalt orvosi eskü szövege is utal erre: „Senkinek sem adok majd mérget, még ha kéri is; sőt még csak ilyen tanácsot sem adok neki" [10]. Ezt egyoldalúan nem lehet az öngyilkosságban való segédlet megtagadásának tekinteni, hiszen mérget arra is kérhettek, hogy azzal mások életét oltsák ki. Hippokratész kortársának, Szókratésznek (Kr. e. 469-399) a tanítványa volt Platón (Kr. e. 427-347), Arisztotelész (Kr. e. 384-322) mestere, aki a nyílméreg elkészítésének módját is részletezte írásaiban. Az athéni filozófiai iskola élén Arisztotelészt a szintén filozófus, de egyben a botanikához is értő Ereszoszi Theophrasztosz (Kr. e. 371-287?) követte. Munkáiban részletesen ismertette a korra jellemző mérgező növényeket és állatokat. A rómaiak átvették a görög kultúrát, így az isteneiket, a tudományukat, a gyógyítást és a növényi mérgek ismeretét is. Idősebb Plinius (Kr. u. 23-79) számos müvet írt a természetben előforduló növényekről és állatok- ról. Ezek közül „csak” a Historica Naturalis 37 kötete maradt az utókorra, amelyekből részleteket tudhatunk meg a gyógynövények felhasználásáról, valamint az állati eredetű mérgek természetéről. Ez az enciklopédikus mü az ásványok és a fémek hatásaival is foglalkozik, például olyan érdekességekkel, hogy a higany-szulfittal dolgozók védték az arcukat a por belélegzése ellen. Ebből arra következtethetünk, hogy tapasztalati úton már az ókorban is észlelték az ásványnak a szervezetre gyakorolt negatív hatásait. Idősebb Pliniust Pompejiben érte a Vezúv pusztító kitörése Kr. u. 79-ben. Ifjabb Plinius (Kr. u. 61113), akit a vulkanológia első tudósának tekintenek, Tacitushoz írott leveleiben számolt be a Vezúv kitöréséről és nagybátyja, idősebb Plinius haláláról. Leírása szerint „mikor azután a lángok és a kéngőz, a lángok hírnöke miatt a többiek futásnak eredtek, ő is felkelt. Két szolgájára támaszkodva felállt, de nyomban összerogyott; gondolom a sưrü gőz akadályozta a légzésben, és elzárta légzőcsövét, amely amúgy is beteg, szúk volt, úgyhogy gyakran fulladozott". Holttestét a kitörés után három nappal Pompeji egyik utcáján fekve találták meg [11].

A már említett Dioszkoridész a De Materia Medica (Gyógyító anyagról) című könyvben több száz gyógynövényt írt le, és a növényi mérgeket eredetük szerint rendszerezte. Ez a könyv az orvostanhallgatók számára évszázadokon át a toxikológiai ismeretek alapját képezte. Toxikológiai tudását természetesen ő is felhasználta jövedelmének növelésére, és ennek érdekében betegeit ízletes gyógyborokkal kezelte, ami igen népszerúvé tette a hozzá fordulók körében. Mint ismeretes, az alkohol kitûnő oldószer, ezért a nem toxikus dózisban beadott növényi alkaloidok hatása kiválóan érvényesült a gyógyborokban, így igencsak kelendő elixíreket lehetett elóállítani több tucat hatóanyag felhasználásával. Dioszkoridész a mérgezések kezelésében hánytatást alkalmazott, azonban ezek az ún. emetikus készítmények a gyomorrontások és az ételmérgezések kezelésére is alkalmasak voltak.

\section{Az újkor toxikológiája}

A mérgezések típusai és azok hatásmechanizmusának megismerése párhuzamosan haladt az orvostudomány fejlődésével, bár még ma is sok a homályos pont, de a leggyakoribb mérgezések okait, hatásaik biokémiai hátterét, sőt az ellenmérgek használatát ma már jól ismerjük. Ennek a folyamatnak a kezdetei a középkorig nyúlnak vissza, amelynek utolsó évszázadaiban a különböző toxikológiai megfigyelések és elméletek minőségükben egyre inkább javultak, a megfigyelések mind tényszerúbbé, a kutatások objektívebbé váltak. Az első példákat erre a szemléletmódra az ipari és foglalkozási toxikológia kezdeteinél találhatjuk. Ulrich Ellborg (1459-1499) német orvos 1473-ban adta ki azt a múvét, amelyben az ötvösöket és aranymúveseket az ólom, a higany és az antimon gőzeinek egészségre gyakorolt hatásaira figyelmeztette. A tudományos megközelítés ennek ellenére igen vontatottan jutott el a szakmai közvélemény tudatáig, és ha 
ma megkérdezünk egy ötvöst vagy autófényezőt arról, hogy milyen védőberendezést, személyi védelmet, légzésvédelmet alkalmaz a munkája során, valószínúleg értetlenül állna a kérdéssel szemben.

Philippus Aureolus Paracelsus (Theophrastus Bombastus von Hohenheim, 1493-1541) svájci orvos volt az, aki a középkor és az újkor fordulóján elsőként mondta ki azt a ma már elfogadott és jól ismert alapelvet, hogy a mérget a dózis teszi méreggé. Tehát minél többet juttatunk a szervezetbe, annál erôteljesebb lesz a hatás. Paracelsust sokan gyúlölték, ugyanis a legkevésbé sem volt tapintatos maradi és merev gondolkodású kortársaival szemben. Georg Bauer (Georgius Agricola, 14941555), Paracelsus kortársa a De Re Metallica címú munkájában leírta a bányászok és a felszíni fejtéseken dolgozók között előforduló gyakori megbetegedéseket, amelyek a mai olvasatban leginkább tuberkulózisnak, karcinómának, illetve szilikózisnak feleltek meg.

Egy évszázad múltán az ipari toxikológia legjelentősebb képviselője az itáliai Bernardino Ramazzini (16331714) volt, akit ma a foglalkozási orvostan atyjának tartunk. Érdeklődésének középpontjában egy szegény munkás állt, akinek nem irigylésre méltó feladata volt az emésztőgödrök tisztítása, és minden nap hosszú órákat töltött el az egészségre ártalmas, bűzös gödrökben. Ramazzini megfigyelte, és rájött, hogy akik ezt a munkát végzik, fényérzékenységtôl szenvednek, és végül megvakulnak. Ez a (kis mennyiségú) krónikus kén-hidrogénexpozíció következménye, a vegyület nyálkahártya-irritáló hatása révén. Számos iparág dolgozói közül a bányászok, a kőmúvesek, a fémipari dolgozók és a fazekasok megbetegedéseit is vizsgálta. Hosszú élete során (82 éves korában halt meg) húsz múvet írt, amelyek közül a legkiemelkedőbb a De Morbis Artificum Diatriba volt. A könyv 1700-ban jelent meg, és terápiás eljárásokat is megfogalmazott.

\section{A modern toxikológia kezdetei}

A legújabb kor toxikológiája hozta magával azt a változást és egyben veszedelmet is, amelyet ma kemizációnak nevezünk. Humphry Davy (1778-1829) 1799-ben leírta a nitrogén-oxidul, azaz a nevetőgáz emberre gyakorolt hatásait. Friedrich Sertürner (1783-1841) német gyógyszerész ópiumból izolálta a morfint (1805), majd 1832-ben a kodeint. A dél-amerikai cinchona fa kérgéból a kinint Pierre Joseph Pelletier (1788-1842) és Joseph Bienaimé Caventou (1795-1887) francia kutatók állították elő először 1817-ben. Az 1800-as évek elején számos korábbi növényi mérget sikerült tisztán előállítani, így a foltos bürök hatóanyagát, a koniint (1826), a dohány alkaloidját, a nikotint (1828) vagy a keserúmandulában található amigdalint (1830).

A modern orvosi toxikológia megalapítója Mathieu J. B. Orfila (1787-1853) spanyol orvos volt, aki főleg Párizsban tevékenykedett. Ô vezette be a toxikológiába az állatkísérleteket, és összefüggésbe hozta a dózist a kivál- tott hatással. Eredményeiről 1814-1815-ben megjelent munkájában, a Toxicologie Générale-ban számolt be. Jelentős eredményeket ért el az igazságügyi toxikológiában is, amiért Orfilát az igazságügyi orvostan megalapítójaként is számon tartjuk. Munkássága mellett ennek a tudományágnak a születését olyan nevek fémjelzik, mint az angol James Marsh (1794-1846) vagy a belgiumi Jean Servais Stas (1813-1891) [12]. Orfila a gyilkosságok áldozataiból utólag is képes volt kimutatni a mérgeket. Ennek módszertanát írta le Leçons de Medicinale Légale (1823) és Traité des Exhumations Juridiques (1830) címú munkáiban. Használta az angol James Marsh által 1836-ban kifejlesztett arzénkimutatási módszert, amelynek segítségével nem csupán a gyomortartalomban, hanem más szövetekben is igazolni lehetett az arzén jelenlétét. Lényegében ez vetett véget a kriminológia arzénmérgezésekkel teli korszakának. Kritikusan szemlélte korának eljárásait a mérgezések gyógyításában, amelyek közül nagyon sokat hatástalannak gondolt. Ajánlásai, például a mérgek gyors eliminációja a szervezetből, valamint a mesterséges lélegeztetés, ma is érvényesek [13]. Orfila nemzetközi elismertsége kapcsán mindenképpen meg kell említenünk, hogy a budapesti Királyi Orvosegyesület 1843-ban levelező tagjává választotta, és az egyesület külföldi tagjai között elsőként képviselte a francia orvostudományt és Franciaországot [14].

Jean Servais Stas 1850-ben a nikotin kimutatásának leírásával járult hozzá az igazságügyi toxikológia sikereihez. Elsóként készített alkoholos kivonatokat a halottak különböző szerveiből, amelyekben sikerrel mutatta ki a nikotin jelenlétét. Ezzel egyben tanítómestere, Mathieu J. B. Orfila egyik fó tantételét is megcáfolta, miszerint lehetetlen volna szerves anyagokból a szerves mérgek kimutatása. Felfedezésével valójában Jean Servais Stas nyitotta meg az utat az összes növényi méreg (alkaloidok) kimutatása előtt. Ezek közül a gyúszúvirág alkaloidja, a digitálisz-glikozid szerepelt az 1860-as években Európaszerte nagy feltűnést keltő mérgezéses bünügyben. A homeopata orvosként Párizsban praktizáló Edmund de la Pommerais (1846-1864) az özvegy Seraphine de Pawr-t nyereségvágyból mérgezte meg digitálisszal, hogy hozzáférhessen az életbiztosításához. A természetesnek tứnő halál után a holttestet egy névtelen feljelentő levél nyomán exhumálták, és a szövetekben egyértelmúen kimutatták a méreg jelenlétét. De la Pommerais-t halálra ítélték, és guillotinnal végezték ki 1864-ben [15].

Gyakorlatilag fontosabb mérgezések címmel a magyar szakirodalomban már a XIX. század végén, 1896-ban, a terjedelmes Belgyógyászat kézikönyve részeként, kitűnő összefoglalás jelent meg a belgyógyász és farmakológus egyetemi tanár Bókay Árpádtól (1856-1919), amelyből több évtizeden keresztül orvosgenerációk egész sora tanulta a klinikai és törvényszéki toxikológiát [16].

Az 1800-as évek elején Angliából kiinduló ipari forradalom nyomán tömeges méretben jelentkeztek a toxikus hatások következtében keletkezett foglalkozási ártalmak 
és betegségek. Charles Turner Thackrah (1795-1833) különleges figyelmet érdemel, aki az ipari forradalom egyik tipikus városában, az angliai Leedsben praktizált. Thackrah betegei mintegy száz különböző iparágban dolgoztak. A fazekasok és festők krónikus ólommérgezését 1831-ben írta le, az iparipor-expozíció után kialakuló tüdőbetegségek, fő́ként a tuberkulózis előfordulását pedig a bányászoknál és a köszörúsöknél [17].

A foglalkozási rákkeltő anyagok (különböző eredetú égéstermékek, kátrány és korom) első leírója Percivall Pott (1714-1788) angol sebészorvos volt, aki 1775-ben a kéményseprók herezacskóbőrén kialakuló bőrrákot a korom hatásával hozta összefüggésbe. Az égéstermékek rákkeltő anyagai a policiklikus aromás szénhidrogének (PAH-ok), amelyek egyik vegyületcsoportjának közös jellemzője a gyưrűs vegyületekből álló gerinc, különböző alkilcsoportokkal. Közös tulajdonságuk, hogy adduktként kötődnek a makromolekulákhoz, ezért más néven alkiláló vegyületeknek is hívjuk őket. Bőven fordulnak elő a nehézipar különböző ágazataiban, a petrolkémiai anyagok, nyersgumi, koksz, bitumen elóállítása és a fémkohászat területén. Részét képezik a kőszénlepárlásnak, a gumigyártásnak, az alumíniumkohászatnak és számos más szerves anyag feldolgozásával és elóállításával foglalkozó iparágnak, például a bitumengyártásnak vagy a kőolaj-feldolgozásnak [18].

Ludwig Rehn (1849-1930) német sebész 1895-ben arra lett figyelmes, hogy az anilinfestéket gyártó munkások körében fokozódott a húgyhólyagrák gyakorisága, és az esetek $20 \%$-át a munka során elszenvedett festékexpozíciónak tulajdonította. A későbbiek során az Egyesült Államokban humánepidemiológiai adatok révén és állatkísérletekben sikerült igazolni, hogy a rákot nem maga az anilin, hanem az oldószerek okozzák (a benzidin és a béta-naftil-amin). Azóta számos festékről igazolódott be, hogy szerepük van a húgyhólyagrák kialakulásában [19].

Schneeberg és Joachimsthal környékén a bányászok között fellépő „járványos” tüdőrákesetek keltették fel két német kutató, F. H. Harting és W. Hesse figyelmét. Beszámolójukat, amelyet 1879-ben készítettek, módszertanilag ma is az ipari toxikológia klasszikus tanulmányának tekintik [20]. Először arzén- és kobaltexpozíciónak tulajdonították a megbetegedéseket, de Hollcroft és Lorenz 1949-ben utánajárt a lehetséges kórokoknak, és tisztázták, hogy az ércbányában előforduló radonexpozíció volt a felelós a „járványos” tüdőrákos esetekért [21]. Annak is a radioaktivitás volt a magyarázata, hogy az 1920-as években a világító óraszámlapokat festő asszonyok körében miért szaporodott meg a mandibula csontrákjának gyakorisága. Számos haláleset után az 1950-es évek elején végre megtiltották a radioaktív világító festékek használatát. Az arzén-trioxid humán tüdőrákot okozó hatását Lee és Fraumeni 1969-ben fedezte fel. Megállapították, hogy az arzén-trioxid különösen kén-dioxid jelenlétében felelős a dolgozók tüdőrákjának kialakításáért. Ezt a megállapítást sokáig nem sikerült igazolni állatkísérletekben, de végül az International Agency for Research on Cancer (IARC) 1987-ben az arzént és vegyületeit a humán rákkeltők közé sorolta.

Irving J. Selikoff (1915-1992) nevéhez füződik az azbeszt rákkeltő hatásának epidemiológiai bizonyítása. Saját biztonságát is veszélyeztetve harcolta ki az 1960-as évek közepén, hogy az építóiparban betiltsák az azbeszt legveszélyesebb kék fajtájának használatát. Azóta is kemény küzdelem folyik a szakma és az építóipar képviselői között, hogy az egész világon tiltsák be végre az azbeszt ipari felhasználását, hiszen jelenleg is évente kb. 125 millió ember érintkezik a munkája során az azbeszt valamilyen formájával. Az azbesztre is igaz, ami korábban ismert volt a radonnal kapcsolatban, nevezetesen, hogy a dohányzás az azbeszt rákkeltő hatását is képes fokozni. Így alakult ki az a becslés, amely szerint évente mintegy 107 ezer tüdőrákos beteg kórelőzményében mutatható ki az azbesztexpozíció. Hazai kutatások is igazolták, hogy a tüdőrákosok jelentôs hányadában (évi kb. 150 eset) maga a tumor is tartalmaz azbesztszálakat, annak ellenére, hogy ezek az esetek nem foglalkozási rákként voltak diagnosztizálva [22].

\section{A szerves kémia kialakulása}

A szerves kémia alapjait Friedrich Wöhler (1800-1882) német vegyész rakta le, aki 1828-ban szintetikus úton állított elő ureát, más néven karbamidot, és ezzel megdöntötte a korábban uralkodó „»is vitalis” elvét. Ennek lényege szerint az életfolyamatok során a szerves vegyületek keletkezése csakis „életerő” révén lehetséges, tehát ilyen anyagokat lehetetlen mesterségesen elóállítani. Felfedezése valóban korszakos áttörés volt az élettudományok és a kémia területén. Így a XIX. század nem csupán a mikrobiológia, hanem a kémia és a toxikológia aranykorát is jelentette. A mérgező gázokról Hermann Eulenberg (1814-1902) munkája 1865-ben jelent meg. Ugyanebben az évben fedezte fel Friedrich August Kekule (1829-1896) a benzolmolekula gyúrús szerkezetét is. A magyar Fodor József (1843-1901) is végzett toxikológiai kutatásokat, hiszen az ő nevéhez füződik a vér szén-monoxid-szintjének kvantitatív meghatározása. Az 1880-as évek végén jelentkezett az 1863-ban alapított Bayer AG a heroin elóállításával, amelynek segítségével a morfinizmust akarták visszaszorítani. Kétségtelenül sikerrel jártak, a használók azonban gyorsabban rászoktak a heroinra, mint a morfinra, és tartósabban függő́vé váltak a morfinistákhoz képest.

Az 1800-as évek közepén a kémiai tudományok gyors fejlődése révén kezdődött a XIX. század vegyipari forradalma, amely óriási tömegben gyártotta és a mai napig is ontja a mesterséges anyagokat. Az 1800-as évek végére már közel 10 ezer vegyületet állítottak elő. Ezek között olyan fontos vegyipari alapanyagok voltak, mint a kloroform, a szén-tetraklorid, a dietil-éter és a petróleum. Ebben a században a vegyészet úttörői a németek voltak, így Oswald Schmiedeberg (1838-1921), aki a máj deto- 
xikációs mechanizmusait tanulmányozta, és Louis Lewin (1850-1929), aki elsóként publikált adatokat a metanol, a glicerin, az akrolein és a kloroform toxicitásáról. Ez magával hozta az analitika fejlődését is, így a II. világháború idején Ausztriában elsőként Erica Kremernek köszönhetően a gázkromatográfia már rutineljárásként szolgálta az ilyen irányú vizsgálatokat.

\section{A mưanyagok térhódítása}

A modern műanyagipar megjelenése hatalmas jelentőségű áttörés volt a korábban használt, gyakran szúkösen rendelkezésre álló nyersanyagokhoz képest, a gyártás során azonban számos toxikus anyagot kell felhasználni, és toxikus melléktermékek is keletkeznek. A gumit 1823ban állították elö, a kaucsukfa nedvének kénnel történő elegyítésével. Több évszázados kísérletezés után az első múselyem szálat cellulóz alapanyagból Hilaire de Chardonnet (1839-1924) készítette, és Chardonnet-selyem néven 1889 -ben mutatta be a párizsi világkiállításon. A robbanásveszélyes gyártási technológia miatt ezt a terméket az 1890-ben megjelent viszkóza, a jelenleg is használt múselyem, igen rövid idő alatt teljesen kiszorította a piacról. Az első valódi, tehát teljesen szintetikusan előállított műanyag az 1907-ben szabadalmaztatott bakelit volt, amelynek tömeggyártása az I. világháború (1914-1918) éveiben kezdődött. Könnyüsége és törésállósága kiválóan alkalmassá tette katonai felszerelések gyártására. Az USA-ban 1938-ban állították elő az első nejlonharisnyát, amelynek azóta is töretlen a világkarrierje. Az 1940-es években sorra jelentek meg a műanyagok, a perlon, az orlon, a terilén, a műgyapjú mint a mai háztartások eszközeinek és a textiliparnak is nélkülözhetetlen alapanyagai. Burkolóanyagként a linóleum felfedezése volt döntő, kiváltotta ugyanis a kő és fa alapanyagokat a lakások padozatának készítésében. Ma már olyan elterjedtek ezek az anyagok, hogy a müanyaggyártás évente eléri a $10^{8}$ tonnát [23].

Jelenleg kb. 10 millióra tehető a szintetikus anyagok elemszáma a világon, és ezekből az ipari fejlettségtől függően 80-100 ezer vegyülettel találkozhatunk nap mint nap a környezetszennyezés miatt. Iparilag szennyezett vidékeken vagy szmogos időszakban ez a szám a kétszeresére is emelkedhet. A XXI. század modern toxikológiája paradigmaváltáson esik át, mivel a hasznossági elvet egyre inkább felváltja a „zöld” vegyipar és gyógyszergyártás, amelyek technológiája arra törekszik, hogy a hatóanyagok minél gyorsabban eliminálódjanak a környezetből, és ne okozzanak ökológiai katasztrófát az élővilág számára. Így a gyógyszerek és vegyszerek forgalomba hozatalát szigorú szabályokhoz kötik, ami egy új tudományág, a kémiai biztonság és minőségbiztosítás révén korlátok közé szorítja a termelést és a fogyasztást. Ennek ellenére sem lehet garantálni a vegyszerek alkalmazásának teljes biztonságát, mert a technológiai fegyelem és az ellenőrzés hiánya mind a mai napig veszélyes helyze- teket teremthet, és folyamatosan ki vagyunk téve valamilyen vegyi katasztrófa lehetőségének. Következésképpen a klasszikus toxikológia után átléptünk az ökológiai toxikológia korszakába, amely már nem történelme, hanem jövője ennek a tudománynak. Ezért a toxikológiai ártalmak ismerete kiemelkedő fontosságú a kortárs medicina és még inkább a jövő orvosai számára.

Anyagi támogatás: A közlemény megírása, illetve a kapcsolódó kutatómunka anyagi támogatásban nem részesült.

Szerzôi munkamegosztás: A szerzők egyenlő arányban vettek részt a kézirat elkészítésében. A cikk végleges változatát mindkét szerző elolvasta és jóváhagyta.

Érdekeltségek: A szerzőknek nincsenek érdekeltségeik.

\section{Irodalom}

[1] Plutarkhosz: Parallel CVs, Alexander the Great and Julius Caesar. [Párhuzamos életrajzok. Nagy Sándor és Julius Caesar.] Osiris Kiadó, Budapest, 2005. [Hungarian]

[2] Ruffin JR. The efficacy of medicine during the campaigns of Alexander the Great. Mil Med. 1992; 157: 467-475.

[3] Schep LJ, Robin J, Slaughter RJ, et al. Was the death of Alexander the Great due to poisoning? Was it Veratrum album? Clin Toxicol. 2014; 52: 72-77.

[4] Galántai J. The First World War. [Az első világháború.] Gondolat Kiadó, Budapest, 1980; p. 277. [Hungarian]

[5] Kerényi K. Greek mythology. [Görög mitológia.] Gondolat Kiadó, Budapest, 1977; pp. 344-364. [Hungarian]

[6] Brósz R, Pólay E. Roman Law. [Római jog.] Tankönyvkiadó, Budapest, 1974; pp. 466-467. [Hungarian]

[7] Bolla I, Rotter F. (eds.) Excerpta of Hungarian historic sources prior to 1526. [Szemelvények az 1526 előtti magyar történelem forrásaiból.] Nemzeti Tankönyvkiadó, Budapest, 1993; pp. 3-18. [Hungarian]

[8] Lizbauer XF. Collection of Hungary's Historic Public Health Legislation. [Codex sanitario-medicinalis Hungariae.] Budae, 1852-1861. II. 456. [Latin]

[9] Györy H. Origin of medicines, the Ebers-papyrus - an old Egyptian papyrus. [„Az orvosságok kezdete”: Az Ebers-papirusz egy ókori egyiptomi orvosi papirusz.] Ókor: folyóirat az antik kultúrákról 2003; 2(2-3): 26-32. [Hungarian]

[10] Havasi L. Selected parts of Hippocrates' works. [Válogatások a Hippokratészi Gyüjteményből.] Gondolat Kiadó, Budapest, 1991. [Hungarian]

[11] Plinius Secundus CC. Letters. Eruption of Vesuvius. [Levelek. A Vesuvius kitörése.] Bibliotheca classica. Európa Kiadó, Budapest, 1981; 6. könyv, 20. levél (ford. Borzsák István). [Hungarian]

[12] Thorwald J. Venom or ways and strays of forensic toxicology. In: Century of the detective. [A méreg, vagy a törvényszéki toxikológia útjai és tévútjai. In: Detektívek százada.] Minerva, Budapest, 1969; pp. 227-354. [Hungarian]

[13] Aggrawal A. History of toxicology. In: Payne-James JJ, Byard RW, Corey TS, et al. (eds.) Encyclopedia of Forensic and Legal Medicine. Elsevier Academic Press, London, 2005; Vol. 2, pp. 525-538.

[14] Kapronczay K. Mathéo Orfila. [Mathéo Orfila.] Orv Hetil. 1978; 119: 1365-1366. [Hungarian] 
[15] Kiss L. On the Hungarian chapter of novel digitalis. [A digitálisz regényének magyarországi fejezete.] Orv Hetil. 2011; 152: 6871. [Hungarian]

[16] Bókai Á, Kétli K, Korányi Fr. Textbook of internal medicine. [A belgyógyászat kézikönyve.] Dobrowsky és Franke, Budapest, 1897. [Hungarian]

[17] Gallo MA. History and scope of toxicology. In: Klaassen CD. (ed.) Casarett and Doull's Toxicology. The basic science of poisons. McGraw Hill Medical Publ Div., New York, NY, 2008; pp. $3-10$

[18] Tompa A. Common toxic substances. In: Multifaceted health awareness. [Mindennapi mérgek. In. Sokszínú egészségtudatosság.] SpringMed Kiadó, Budapest, 2015; pp. 53-65. [Hungarian]

[19] Lane RW, Bozelleca F. Harming and helping through time: The history of toxicology. In: Hayes AW, Kruger CL. (eds.) Hayes' Principles and Methods of Toxicology, 6th edition. CRC Press, Boca Raton, FL, 2007.

[20] Harting FH, Hesse W. The lung cancer, as a mountain disease in the mines of Schneeberg. [Der Lungenkrebs, die Bergkrankheit in den Schneeberger Gruben. Vierteljahrsschrift F. Gericht. Med. u. Offentl. Gesundheitswesen. 1879; 30: 296-309, 31: 102-129, 313-337. [German]

[21] Greenberg M, Selikoff IJ. Lung cancer in the Schneeberg mines: a reappraisal of the data reported by Harting and Hesse in 1879 . Ann Occup Hyg. 1993; 37: 5-14.

[22] Nyirkos P. Evidence-based medicine, proposed methodology. [Tényeken alapuló orvostudomány. Módszertani ajánlások.] Melania Kiadó, Budapest, 2005. [Hungarian].

[23] Hodgson E. Introduction to toxicology. In: A textbook of modern toxicology. Chapter 1, 3-9. Third edition. John Wiley \& Sons, Inc., Hoboken, NJ, 2004. Available from: http://onlinelibrary.wiley.com/doi/10.1002/0471646776.chl/summary

(Tompa Anna dr., Budapest, Nagyvárad tér 4., 1089 e-mail: tompa.anna@gmail.com)

\section{Felhívás és értesítő}

\section{magyar egészségügyi dolgozók (orvos, fogász, gyógyszerész, tudományos kutató, ápoló, asszisztens, gyógytornász, szociális munkás, stb.) részére}

\section{Nemzetközi orvos-képzőművész kiállítás-sorozat Idöpont: 2018. május 12. - Zágráb, Horvátország Jelentkezési határidő: 2018. január 31.}

További információ és komplett jelentkezési anyag elektronikusan a palotas@asklepios-med.eu e-mail címen kérhető.

Bármilyen képzőművészeti alkotás bemutatható (festmény, szobor, kisplasztika, ékszerek, míves használati tárgyak, fotó, stb.). Semmiféle „szelekció”, előbírálat, versenyeztetés, pályázati kiválogatás, avagy „cenzúra” nincs.

A rendezvény non-profit módon kerül megrendezésre: teljesen térítésmentes a részvétel, azaz mind a művek kiállítása, mind pedig a közönség soraiban történő megjelenés mindenki számára ingyenes.

A világ minden tájáról várunk müvész kollégákat, így lehetőség nyílik hazai és külföldi orvosokkal, egészségügyi dolgozókkal szakmai, valamint kulturális kapcsolat felvételére is.

Nagy tisztelettel kérem, hogy kollégái, ismerősei körében legyen kedves terjeszteni a művészeti esemény hírét, hogy minél többen vehessünk részt ezen a nemében egyedülálló nemzetközi kulturális rendezvénysorozaton, mind kiállítóként, mind pedig vendégként!

Együttműködésüket, valamint a rendezvényen való részvételüket elöre is köszönöm!

Tisztelettel

Dr. Palotás András (MD, PhD)

alapító és vezető

Asklepios-Med (www.asklepios-med.eu)

Telefon: +36 (30) 255-6225

E-mail: palotas@asklepios-med.eu

H-6722 Szeged, Kossuth Lajos sgt. 23. 